MAŁGORZATA CUŻYTEK (D) orcid.org/0000-0002-7294-5586

Instytut Psychologii Uniwersytet Jagielloński w Krakowie Institute of Psychology, Jagiellonian University in Kraków e-mail: malgorzata.cuzytek@doctoral.uj.edu.pl

\title{
Nancy Sulla (2018), Building Executive Function: The Missing Link to Student Achievement, London-New York: Routledge - Taylor \& Francis Group
}

Książka Building Executive Function: The Missing Link to Student Achievement wydana została przez Routledge (grupaTaylor \& Francis) w 2018 roku. Jej autorka, Nancy Sulla, EdD (Doctor of Education), stworzyła serię pięciu poradników dla specjalistów związanych z edukacją. Ich celem jest upowszechnianie metody pracy z uczniami, opartej na nowocześnie pojmowanych formach uczenia się i nauczania. Sulla jest propagatorką przekształcania środowisk edukacyjnych w kierunku budowania zaangażowania, autonomii i samoskuteczności uczniów. Idee zawarte w książkach upowszechnia w formie wykładów i odczytów w Stanach Zjednoczonych i Europie (część jej wystąpień odnaleźć można między innymi na platformie TED). Sulla prowadzi także edukacyjną firmę konsultingową (IDE - Innovative Designs for Education), która zajmuje się tworzeniem praktycznych rozwiązań dla edukacji w postaci między innymi programów wzmacniających rozwój funkcji zarządzających u uczniów, opartych na najnowszej wiedzy teoretycznej w tej dziedzinie. Część swojego dorobku udostępnia nauczycielom i specjalistom szkolnym w ramach nieodpłatnej licencji.

Recenzowana pozycja liczy 180 stron i składa się ze wstępu, dziewięciu rozdziałów oraz dodatku, w którym zamieszczone zostały materiały poglądowe, omówione szerzej w poszczególnych rozdziałach, gotowe do wykorzystania przez nauczycieli podczas lekcji (w wersji anglojęzycznej). Książka została wydana po angielsku, lecz operuje na tyle prostym, opisowym językiem, że mimo braku polskiego tłumaczenia czytelnik o średnim poziomie zaawansowania poradzi sobie z percepcją zawartych w niej treści.

Sulla podkreśla wielokrotnie w swoim poradniku, że w dobie nieograniczonego dostępu do wiedzy powoli i nieubłaganie tracą znaczenie same treści nauczania, zyskują zaś sposoby efektywnego uczenia się oraz gotowość poszerzania wiedzy przez całe życie. Efektywności nauczania i samodzielnego uczenia się sprzyjać miałby rozwój (stymulacja) funkcji zarządzających. Nauczyciele starają się przekazywać posiadaną wiedzę w sposób rzetelny i przystępny, nawet jednak najlepiej przygotowany od strony metodycznej pedagog nie jest w stanie przekazać ważnych informacji uczniowi, który nie jest przygotowany do ich przetworzenia i zasymilowania. Aby tak się stało, dziecko musi opanować umiejętność skupiania się na treści lekcji, wychwytywania kluczowych informacji oraz błędów i nieścisłości, identyfikowania związków przyczynowo-skutkowych. Dobrze rozwinięte funkcje zarządzające to, zdaniem wielu teoretyków i praktyków, brakujące ogniwo niezbędne do bardziej efektywnej nauki. Sulla w swojej książce próbuje udowodnić, że nauczyciel - poprzez zastosowanie odpowiedniej kombinacji działań, struktur i strategii podczas lekcji - może stymulować rozwój tych funkcji, tym samym pomagając uczniom $\mathrm{w}$ osiąganiu sukcesu na różnych etapach edukacyjnych.

Recenzowana pozycja ze względu na jej praktyczny wymiar stanowi interesującą, popartą najnowszą wiedzą teoretyczną z dziedziny psychologii rozwojowej, poznawczej i neuropsychologii 
propozycję dla osób zainteresowanych korzystaniem z najnowszych osiągnięć nauki w praktyce. Z inspiracji w niej zawartych skorzystają przede wszystkim psycholodzy i pedagodzy szkolni, pracownicy poradni PP, osoby zajmujące się terapią dzieci i młodzieży o specjalnych potrzebach edukacyjnych oraz nauczyciele chcący poprawić efektywność nauczania swojego przedmiotu.

W rozdziale pierwszym zatytułowanym „Moc, obietnica i pułapki funkcji zarządzających" autorka porusza kwestię roli współczesnej szkoły w przygotowaniu uczniów do wyzwań przyszłości. Wspomina, że wraz z czwartą rewolucją przemysłową i rozwojem sztucznej inteligencji zmienia się społeczny sposób patrzenia na kompetencje uczniów i przyszłych pracowników, którzy w przeważającej większości (jeśli wierzyć raportowi World Economic Forum z 2016 roku) ${ }^{1}$ będą pracować w zawodach, które jeszcze nie istnieją, rozwiązując problemy, jakich ludzkość jeszcze nie napotkała. Świadome kształtowanie umiejętności życiowych, takich jak: samokontrola, zaangażowanie, współpraca, wzmocnienie, samoskuteczność i przywództwo (szeroko omówionych w książce - każdej z nich został poświęcony oddzielny rozdział) powinno się stać, zdaniem Sulli, nadrzędnym celem formalnej edukacji, gdyż przełoży się na dobre funkcjonowanie społeczne i zawodowe przyszłych absolwentów. Kluczem zaś do nabywania owych sześciu coraz bardziej złożonych umiejętności życiowych byłyby sprawnie działające funkcje zarządzające, a w szczególności pamięć robocza (Working Memory) elastyczność poznawcza (Cognitive Flexibility), planowanie (Planning) i rozwiązywanie problemów (Reasoning Problem-Solving) w zakresie organizacji (Organization) oraz kontrola hamowania (Inhibitory Control) oraz samoświadomość (Self-Awareness) w obszarze samokontroli (Self-Regulation). I ta właśnie myśl została zawarta w tytule książki i znalazła swoje rozwinięcie w jej treści.

Pierwszy rozdział to także krótkie wprowadzenie do istoty i rozwoju funkcji zarządzających z punktu widzenia neuropsychologii. Po krótkiej charakterystyce wybranych EF (Executive Function) autorka opisuje ich rozwój.
Zwraca także uwagę na negatywny wpływ przewlekłego stresu na rozwój kory przedczołowej, która jest również siedliskiem EF. Podkreśla jednocześnie rolę nauczycieli w stymulowaniu prawidłowego rozwoju funkcji zarządzających u uczniów poprzez tworzenie warunków edukacyjnych pozbawionych bodźców wzmagających lęk.

Kolejnych sześć rozdziałów to opisy wspomnianych wyżej umiejętności życiowych według podobnego schematu: charakteryzując daną umiejętność, autorka za każdym razem omawia aktywności, jakie mogą podejmować uczniowie i nauczyciele, aby rozwinąć daną kompetencję, oraz funkcje zarządzające niezbędne do ich rozwinięcia, struktury, czyli przykłady konkretnych rozwiązań i ćwiczeń do wykorzystania w różnych sytuacjach edukacyjnych. W podsumowaniu zaś znajduje się zbiór najważniejszych zagadnień, a całość wieńczy odwołanie do literatury przedmiotu. Dzięki takiemu ułożeniu treści czytelnik może sam zdecydować o kolejności czytania poszczególnych rozdziałów oraz W zależności od potrzeb wybiórczo korzystać z zawartości książki.

Pierwsza została omówiona świadoma kontrola (\#EF_ConsciousControl), rozumiana jako umiejętność koncentrowania się i kontrolowania myśli i działań, szczególnie w obszarze zachowań społecznych. W ramach proponowanych aktywności znalazły się między innymi: odtwarzanie z pamięci jak największej liczby szczegółów różnych elementów, wizualizacja czynności przed ich wykonaniem, ćwiczenia wzmacniające przełączanie z tematu na temat bez utraty wątku czy przywoływanie tematu przewodniego w przypadku wtrącenia dygresji niepowiązanej $\mathrm{z}$ tematem przewodnim. Zamieszczono tu także krótki opis różnych aktywności pozaszkolnych wzmacniających wybrane EF (memory, gra na instrumencie, gra w szachy, uczenie się treści piosenek wraz z choreografią itp.).

Rozdział kolejny poświęcony jest zaangażowaniu (\#EF Engagement), definiowanemu jako myślenie o wielu koncepcjach jednocześnie, identyfikowanie związków przyczynowo-skutkowych i utrzymywanie uwagi na zadaniu mimo rozpraszających bodźców. Proponowane aktywności ogniskują się na ćwiczeniu 
umiejętności pełnego skupienia na studiowanej treści z wykorzystaniem wszystkich analizatorów (wzrok, słuch dotyk itp.), dociekania, wyrabiania w uczniach nawyku zadawania pytań: „Czy mogę to zobaczyć w inny sposób?”, „Czy można to rozumieć inaczej?”. Podkreślono także wagę tworzenia kategoryzacji, badania relacji przyczynowo-skutkowych między innymi poprzez pracę metodą projektów edukacyjnych, wykorzystanie elementów dramy i odgrywania ról, tworzenie graficznych planów działania oraz spisów procedur, aby wizualizować i porządkować zagadnienia abstrakcyjne.

Rozdział dotyczący opanowania sztuki wspólpracy ( $\# E F \_$Collaboration) koncentruje czytelnika na uczeniu się mającym charakter społeczny. Współpraca wiąże się z silnym zaangażowaniem, swobodnym korzystaniem z pomysłów innych bez rywalizacji, do tego zaś potrzebna jest elastyczność, otwartość na inny punkt widzenia, radzenie sobie $\mathrm{z}$ dystraktorami podczas wspólnej pracy i wytrwałość w poszukiwaniu wspólnych rozwiązań. Zgodnie z efektem synergii grupowej przy dobrej współpracy mała grupa prawdopodobnie znajdzie lepsze rozwiązania problemów niż pojedyncza osoba; zależy to jednak od poziomu kompetencji i umiejętności komunikacyjnych jej członków. W rozdziale znaleźć można wiele interesujących pomysłów, jak angażować uczniów w proces uczenia się kooperatywnego.

Kolejny rozdział definiuje wzmocnienie (\#EF Empowerment) jako osiągnięcie autonomii i samoświadomości, które pozwala odpowiedzialnie realizować własne potrzeby, pragnienia i pomysły. Do tego konieczna jest umiejętność wyznaczania celów, zarządzania czasem, a funkcje zarządzające wspierające ich nabywanie to głównie elastyczność poznawcza oraz planowanie i samoświadomość. $\mathrm{W}$ tej części autorka główny nacisk położyła na opis ćwiczeń i struktur wzmacniających wyznaczanie celów, pogłębianie rozumienia sensu wykonywanych czynności oraz percepcję upływającego czasu i planowania zadań tak, by uwzględniać krótszą i dłuższą perspektywę czasową.

Samoskuteczność (\#EF_Efficacy) rozumiana jako umiejętność organizowania myśli i aktywności, tworzenia obrazów mentalnych przyszłych działań i przewidywania ich wyników wymaga sprawnych funkcji zarządzających w obszarze planowania, samoświadomości oraz rozwiązywania problemów. Kreatywność to generowanie nowych pomysłów i procesów, wyobrażanie sobie tego, co jeszcze nie istnieje. Jest to mentalny proces łączenia rzeczy, idei w nowy, oryginalny, nietypowy sposób. W zasadzie cały omawiany rozdział został poświęcony prezentacji aktywności i ćwiczeń z obszaru kreatywności i ma za zadanie wzmacniać w klasie tak zwaną kulturę kreatywności, czyli otwartość na nowe idee, rozwiązania, aktywne zaspokajanie naturalnej ciekawości poznawczej uczniów.

Przywództwo (\#EF_Leadership) w recenzowanej pozycji rozumiane jest jako zdolność do inspirowania i wywierania wpływu na ludzi, przy czym Sulla podkreśla wyraźnie, że nie chodzi o to, by każdy uczeń przewodził innym, lecz by rozwijał w sobie empatię oraz skłonność do angażowania się w rozwiązywanie rzeczywistych problemów w szkole czy społeczności lokalnej, co z kolei buduje jego odwagę, pewność siebie i poczucie samoskuteczności.

Ostatecznie Sulla zajmuje się kwestią roli nauczyciela we współczesnym systemie edukacji, przypisując mu, oprócz zadań dydaktycznych, głównie rolę facylitatora - osoby, która ułatwia proces aktywnego poszukiwania wiedzy, udostępnia informacje, dbając o wiarygodność źródeł, wreszcie czuwa nad przebiegiem indywidualnej i zespołowej pracy uczniów zgodnie ze schematem: „Obserwuj, pytaj, instruuj, proponuj, integruj, zachęcaj, doceniaj". Czy pomysł ten jest całkowicie innowacyjny? Niekoniecznie, biorąc pod uwagę bogaty dorobek szkół Montessori, waldorfskich lub pracę metodą projektów edukacyjnych czy idee oceniania kształtującego. Odnoszę wrażenie, że autorce chodzi o upowszechnienie tych sposobów pracy z dziećmi i młodzieżą w szkołach masowych, co jest pewnym wyzwaniem, gdyż wymaga świadomych, zaangażowanych i otwartych na zmiany, kreatywnych nauczycieli, którzy dodatkowo posiadają sporą wiedzę na temat rozwoju funkcji zarządzających i podejmują zaplanowane działania, aby je wzmacniać w swoich uczniach. 
Część metod i propozycji dydaktycznych zawartych w książce może być inspiracją dla czytelników do refleksji nad zmianą myślenia o roli nauczyciela i systemu edukacyjnego w przygotowaniu młodego pokolenia do wyzwań współczesności. Jako zbiór praktycznych porad pozycja stanowi materiał do wykorzystania podczas lekcji oraz zajęć pozalekcyjnych (rewalidacyjnych, korekcyjno-kompensacyjnych, terapii pedagogicznej).
Ja doceniam jej rolę w popularyzowaniu i upowszechnianiu wiedzy na temat funkcji zarządzających w środowiskach edukacyjnych, bo, jak dotąd, wiedza ta jest szczątkowa. Dzięki zaś licznym przykładom i ćwiczeniom Sulla udowadnia, że można wzmacniać funkcje zarządzające uczniów podczas pracy z całym zespołem klasowym, realizując jednocześnie treści zawarte w podstawie programowej każdego przedmiotu.

\section{PRZYPIS}

1 World Economic Forum (2016), The Future of Jobs: Employment, Skills, and Workforce Strategy for the Fourth Industrial Revolution. Geneva: World Economic Forum. 